\title{
Kepemimpinan transformasional dan transaksional terhadap perilaku inovatif: Mediasi oleh variabel psychological empowerment
}

\author{
Agi Syarif Hidayat ${ }^{1}$, Hilmiana ${ }^{2}$ \\ ${ }^{1}$ Universitas Swadaya Gunung Jati \\ Jl. Pemuda Raya No.32, Sunyaragi, Kec. Kesambi, Kota Cirebon, Jawa Barat 45132, Indonesia \\ ${ }^{2}$ Universitas Padjajaran \\ Jl. Dipati Ukur No.35, Bandung 40132, Indonesia \\ *Koresponden: agi.unswagati@gmail.com
}

\author{
Artikel Info \\ Received: \\ 30 Agustus 2020 \\ Revised: \\ 18 Oktober 2020 \\ Accepted: \\ 30 Oktober 2020
}

\begin{abstract}
ABSTRAK
Tujuan penelitian ini adalah untuk mengetahui signifikansi pengaruh kepemimpinan transformasional dan transaksional terhadap perilaku inovatif dengan Psychological empowerment sebagai variabel mediator. Metode penelitian yang digunakan adalah metode penelitian kuantitatif. Populasi dalam penelitian ini adalah Karyawan Perusahaan Daerah Air Minum (PDAM) Kota Cirebon dengan jumlah populasi sebenyak 203 orang. Teknik pengukuran sampling menggunakan rumus slovin dengan margin of eror $10 \%$, sehingga ditentukan jumlah sampel dalam penelitian ini adalah 67 responden. Teknik penarikan sampel menggunakan pendekatan incidental sampling. Teknik penarikan data yang digunakan adalah kuesioner dengan skala likert. Teknik analisis data yang digunakan adalah menggunakan teknik analisis jalur (Path Analysis). Hasil penelitian menunjukan bahwa kepemimpinan transformasional memiliki pengaruh signifikan terhadap periaku inovatif baik secara langsung maupun dimediasi oleh variabel psychological empowerment. Variabel kepemimpinan transaksional tidak memiliki pengaruh signifikan terhadap perilaku inovatif baik secara langsung maupun dimesiasi oleh variabel psychological empowerment. Variabel psychological empowerment memiliki pengaruh signifikan terhadap peningkatan perilaku inovatif.
\end{abstract}

Kata Kunci : Kepemimpinan transformasisonal; kepemimpinan transaksional; psychological empowerment; perilaku inovatif

\section{Transformational and Transactional Leadership on Innovative Behavior: Mediated by Psychological Empowerment variables}

Published by Jurnal Ilmiah Manajemen dan Bisnis, Indonesia | Copyright (C) 2020 by the Author(s) | This is an open access article distributed under the Creative Commons Attribution License http://creativecommons.org/licenses by/4.0), which permitsunrestricted use, distribution, and reproduction in any medium, provided the original work is properly cited.

\begin{abstract}
.
The purpose of this study was to determine the significance of the effect of transformational and transactional leadership on innovative behavior with psychological empowerment as the moderator variable. The research method used is quantitative research methods. The population in this study were employees of the Regional Drinking Water Company (PDAM) of Cirebon City with a total population of 203 people. The sampling measurement technique used the Slovin formula with a margin of error of $10 \%$, so the number of samples in this study was determined to be 67 respondents. The sampling technique uses the incidental sampling approach. The data collection technique used was a questionnaire with a Likert scale. The data analysis technique used is path analysis. The results showed that Transformational leadership had a significant effect on innovative behavior either directly or mediated by psychological empowerment variables. The transactional leadership variable did not have a significant effect on innovative behavior either directly or mediated by psychological empowerment variables. The psychological empowerment variable has a significant effect on increasing innovative behavior.
\end{abstract}

Keyword : Transformational leadership; transactional leadership; psychological empowerment; innovative behavior

DOI: https://doi.org/10.30596/jimb.v21i2.5125

JEL CLASSIFICATION: O, O1, 015

Cara Sitasi :

Hidayat, A. S., Hilmiana. (2020). Kepemimpinan Transformasional dan Transaksional terhadap Perilaku Inovatif: Dimediasi variabel Psycholigical Empowement. Jurnal Ilmiah Manajemen dan Bisnis, 21(2), 149-156. https://doi.org/10.30596/jimb.v21i2.5125. 


\section{PENDAHULUAN}

Konsep inovasi organisasi menarik untuk dikaji dalam presfektif manajemen sumber daya manusia. Terdapat keterkaitan yang kuat antara inovasi dengan sumber daya manusia. Inovasi adalah gagasan baru yang diterapkan untuk memperbarui suatu produk atau proses dan jasa sehingga dapat memberikan nilai tambah (value added) (Robbins \& Judge, 2018). Kegiatan inovasi tidak dapat dilepaskan dari sumber daya manusia sebagai pelaku inovasi itu sendiri.

Salah satu kajian penting yang berkaitan dengan inovasi organisasi adalah mengenai innovative behavior atau perilaku inovatif. Hasil riset Dyer, Gregersen, \& Christensen, (2011) menunjukan bahwa perilaku inovatif karyawan bukan hanya sesuatu yang sifatnya genetis akan tetapi sebuah hal yang bisa dipelajari serta dapat diajarkan kepada para karywan. Perilaku inovatif karyawan merupakan salah satu determinan terbentuknya inovasi organisasi. Berdasarkan hasil riset tersebut penting untuk dikaji lebih lanjut mengenai perilaku inovatif.

Perilaku inovatif merupakan aktivitas individu yang berorientasi pada permunculan ide, pengenalan ide serta implementasi dari sesuatu yang dianggap baru dan memberikan keuntungan pada organissi (Kleysen \& Street, 2011). Beberapa hasil penelitian menjelaskan faktor-faktor yang mempengaruhi perilaku inovatif karyawan, salah satu faktor yang paling dominan adalah kepemimpinan transformasional (Jong \& Hartog, 2007; Lako, 2004).

Kepemimpinan transformasional merupakan sebuah gaya dalam memimpin dimana pada situasi tersebut para anggota atau pengikut memiliki kepercayaan kepada pemimpin mereka, adanya loyalitas serta rasa hormat dan termotivasi untuk memberikan yang terbaik kepada pemimpin. (Avolio \& Bass, 1995). Kepemimpinan transformasional memberikan dampak signifikan terhadap perilaku inovatif karena dengan gaya kepemimpinan yang mampu menstimulasi kemampuan karyawan, maka karyawan akan mampu berperilaku inovatif.

Terdapat hasil penelitian menarik yang dipublikasikan oleh Pieterse, Knippenberg, Schippers, \& Stam, (2010) yang menganalisis pengaruh atau dampak dari penerapan kepemimpinan transformasional serta kepemimpinan tansaksional terhadap peningkatan perilaku inovatif karyawan. Penelitian ini dilakukan pada lembaga pemerintahan di negara Belanda. Peneliti tersebut mengidentifikasi bahwa karyawan pada lembaga pemerintah baik itu yang bergerak dalam bidang pelayanan atau bisnis memiliki perilaku inovasi yang rendah. Pada penelitian tersebut, peneliti menggunakan kombinasi dua gaya kepemimpinan transformasional dan transaksional sebagai faktor yang mempengaruhi perilaku inovatif karyawan dengan variabel Psychological empowerment sebagai variabel mediator. Temuan penelitian tersebut menunjukan bahwa kepemimpinan transformasional berpengaruh signifikan dengan perilaku inovatif hanya jika pemberdayaan psikologis tinggi, sedangkan kepemimpinan transaksional memiliki hubungan negatif dengan perilaku inovatif.

Terdapat beberapa hal yang menarik dalam penelitian ini yaitu 1) peneliti memasukan variabel kepemimpinan transaksional dan ternyata memiliki pengaruh yang negatif terhadap perilaku inovatif, itu artinya penerapan gaya kepemimpinan yang transaksional akan mereduksi perilaku inovatif karyawan, 2) hasil penelitian menunjukan bahwa tidak terdapat pengaruh signifikan antara kepemimpinan transformasional terhadap perilaku inovatif, hal ini memiliki perbedaan mendasar dengan hasil penelitian yang menunjukan bahwa adanya pengaruh signifikan antara kepemimpinan transformasional terhadap perilaku inovatif (Aryee, Walumbwa, Zhou, \& Chad, 2012; Kresnandito, 2012; Parashakti, Rizki, \& Saragih, 2016). Dalam penelitian ini dijelaskan bahwa pola hubungan kepemimpinan transformasional terhadap perilaku inovatif itu baru akan efektif apabila memasuka variabel Psychological empowerment sebagai variabel mediator.

Hasil penelitian terdahulu yang menunjukan adanya kesenjangan hasil penelitian mengenai pengaruh kepemimpinan transformasional terhadap perilaku inovatif serta temuan penelitian 
yang kontroversial mengenai keterkaitan kepemimpinan transaksional terhadap perilaku inovatif menjadi motivasi peneliti untuk menguji kembali pengaruh kepemimpinan transformasional dan transaksional terhadap perilaku inovatif melalui psychological empowerment sebagai variabel mediator.

\section{METODE}

Penelitian ini menggunakan metode kuantitatif. Populasi penelitian adalah Karyawan Perusahaan Daerah Air Minum (PDAM) Kota Cirebon dengan jumlah 203 orang. Berdasarkan perhitungan jumlah sampel mengunakan rumus slovin (margin of error 10\%), ditetapkan jumlah sampel sebanyak 67 responden. Teknik penarikan sampling dalam penelitian ini menggunakan pendekatan insidental sampling.

Terdapat 4 variabel dalam penelitian ini. Dimensi dalam kepemimpinan Transformasional meliputi : 1) idelized influence, 2) Inspirational motivation, 3) intelectual stimulation, 4) individual consideration (Bass \& Riggio, 2006). Dimensi dalam kepemimpinan transaksional meliputi : 1) contingent reward, 2) active management by exception dan 3) passive management by exception (Bass \& Riggio, 2006). Terdapat 4 dimensi dalam Pshycological empowerment yaitu 1) meaning, 2) competence, 3) self-determination, 4) impact (Spreitzer, 1995). Terdapat 5 Dimensi dalam variabel perilaku inovatif yaitu : 1) Opportunity Exploration, 2) Generativity, 3) Formative Investigation, 4) Championing, 5) Apllication (Kleysen \& Street, 2011)

Penarikan data untuk keperluan olah data menggunakan kuesioner dengan skala pengukuran instrumen menggunakan skala likert $1-5.5=$ sangat setuju, $4=$ setuju, $3=$ cukup setuju, 2 = tidak setuju, 1 = sangat tidak setuju. Berikut ini contoh instrumen kuesioner pada setiap variabel : Saya mampu menghasilkan ide atau solusi untuk menyelsaikan masalah di tempat kerja (variabel perilaku inovatif), Pimpinan mendorong para bawahan untuk berfikir kreatif dan inovatif dalam bekerja (variabel kepemimpinan transformasional), Pimpinan akan memberi imbalan apabila mampu melakukan pekerjaan sesuai dengan target (variabel kepemimpinan transaksional), Saya percaya diri tentang kemampuan saya untuk melakukan kegiatan pekerjaan saya (Psychological empowerment). Teknik analisis data dalam penelitian ini menggunakan teknik analisis jalur dengan bantuan aplikasi PLS SEM.

\section{HASIL DAN PEMBAHASAN} ini :

Hasil pengolahan data mengenai karakteristik responden ditampilkan dalam tabel dibawah

Tabel 1. Karakteristik responden

\begin{tabular}{lcc}
\hline Pilihan & Frekuensi & Persen \\
\hline $\begin{array}{l}\text { Jenis kelamin } \\
\text { Laki-laki }\end{array}$ & 58 & 87 \\
$\quad$ Perempuan & 9 & 13 \\
Usia & 7 & 10 \\
$\quad<30$ & 40 & 60 \\
$31-40$ & 19 & 28 \\
$41-50$ & 1 & 1 \\
$>51$ & & 72 \\
Pendidikan & 48 & 28 \\
$<$ S1 & 19 & 0 \\
S1 & 0 & \\
S2 & & 3 \\
Masa kerja & 2 & 37 \\
$1-5$ tahun & 25 & 60 \\
$6-10$ tahun & 40 & \\
$>10$ tahun & &
\end{tabular}


Berdasarkan table $\mathrm{F}$ mengenai karakteristik responden diketahui bahwa mayoritas responden memiliki jenis kelamin laki-laki yaitu sebanyak 58 responden atau $87 \%$ dari total responden. Berdasarkan karakteristik usia mayoritas responden berusia 31-40 tahun yaitu sebanyak 40 responden. Berdasarkan tingkat pendidikan mayoritas responden memiliki tingkat pendidikan dibawah sarjana yaitu sebanyak 48 responden. Berdasarkan masa kerja mayoritas responden memiliki masa kerja diatas 10 tahun yaitu sebanyak 40 responden.

Hasil pengujian reliabilitas instrumen ditampilkan dalam tabel construct reliability dibawah ini :

Tabel 2. Construct reliability

\begin{tabular}{lcccc}
\hline & Cronbach's Alpha & rho_A & CR & (AVE) \\
\hline Innovative behavior & 0.809 & 0.825 & 0.850 & 0.504 \\
Psyhcological behavior & 0.939 & 0.941 & 0.946 & 0.542 \\
Transformational leadership & 0.888 & 0.912 & 0.912 & 0.600 \\
Transactional ledership & 0.802 & 0.846 & 0.846 & 0.503 \\
\hline
\end{tabular}

Sumber : hasil pengolahan data menggunakan aplikasi SMART PLS, 2020.

Berdasarkan hasil pengujian reliabilitas instrumen, diketahui bahwa seluruh variabel dalam penelitian ini adalah reliabel karena nilai Cronbach's Alpha $>0,7$. Nilai Average Variance Extracted (AVE) diatas 0,5 sehingga disimpulkan seluruh variabel dalam penelitian ini memenuhi asumsi reliabilitas.

Pengujian hipotesis penelitian disajikan dalam tabel path coefficient dibawah ini :

Tabel 3. Path Coefficients

\begin{tabular}{lccccc}
\hline & $\begin{array}{c}\text { Original } \\
\text { Sample (O) }\end{array}$ & $\begin{array}{c}\text { Sample } \\
\text { Mean } \\
(\mathbf{M})\end{array}$ & $\begin{array}{c}\text { Standard } \\
\text { Deviation } \\
\text { (STDEV) }\end{array}$ & $\begin{array}{c}\text { T Statistics } \\
(|\mathbf{O} / \mathbf{S T D E V}|\end{array}$ & $\begin{array}{c}\text { P } \\
\text { Values }\end{array}$ \\
\hline $\begin{array}{l}\text { Psyhcological empowerment - } \\
\text { Innovative behavior }\end{array}$ & 0.315 & 0.327 & 0.106 & 2.963 & 0.003 \\
$\begin{array}{l}\text { Transactional leadership - }> \\
\begin{array}{l}\text { Psyhcological empowerment } \\
\text { Transactional leadership - }>\end{array}\end{array}$ & 0.180 & 0.173 & 0.127 & 1.416 & 0.157 \\
$\begin{array}{l}\text { innovative behavior } \\
\text { Transformational leadership - }>\end{array}$ & 0.031 & 0.027 & 0.062 & 0.500 & 0.617 \\
$\begin{array}{l}\text { Psyhcological empowerment } \\
\text { Transformational behavior - }>\end{array}$ & 0.653 & 0.660 & 0.077 & 8.191 & 0.000 \\
innovative behavior & 0.634 & 0.108 & 6.018 & 0.000 \\
\hline
\end{tabular}

Berdasarkan hasil pengujian hipotesis diketahui bahwa : 1) Psychological empowerment memiliki pengaruh signifikan terhadap innovative behavior karena nilai $\mathrm{P}$ values $<0.05 .2$ ) Transformational leadership memiliki pengaruh signifikan terhadap innovative behavior karena nilai $\mathrm{P}$ values $<0.05$. 3) Transformational leadership memiliki pengaruh signifikan terhadap psychological empowerment karena nilai $\mathrm{P}$ values $<0.05$. 4) Transactional leadership tidak memiliki pengaruh signifikan terhadap innovative behavior karena nilai $\mathrm{P}$ values $>0.05$. 5) Transactional leadership tidak memiliki pengaruh signifikan terhadap Psychological empowerment karena nilai $\mathrm{P}$ values $>0.05$.

Hasil pengujian hipotesis pengaruh kepemimpinan transformasional dan kepemimpinan transaksional terhadap perilaku inovatif yang dimediasi oleh psychological empowerment ditampilkan dalam tabel berikut ini : 
Tabel 4. Spesifict Indirect Effect

\begin{tabular}{|c|c|c|c|c|c|c|}
\hline & & $\begin{array}{l}\text { Original } \\
\text { Sample } \\
\text { (O) }\end{array}$ & $\begin{array}{c}\text { Sample } \\
\text { Mean } \\
\text { (M) }\end{array}$ & $\begin{array}{l}\text { Standard } \\
\text { Deviation } \\
\text { (STDEV) }\end{array}$ & $\begin{array}{l}\text { T Statistics } \\
\text { (|O/STDEV|) }\end{array}$ & $\begin{array}{c}P \\
\text { Values }\end{array}$ \\
\hline Transactional & $0->$ & 0.056 & 0.054 & 0.046 & 1.215 & 0.225 \\
\hline $\begin{array}{l}\text { psychological empowerment } \\
\text { Innovative behavior }\end{array}$ & & & & & & \\
\hline $\begin{array}{l}\text { Transformational leadership } \\
\text { psychological empowerment } \\
\text { innovative behavior }\end{array}$ & $\begin{array}{l}-> \\
->\end{array}$ & 0.195 & 0.215 & 0.086 & 2.273 & 0.023 \\
\hline
\end{tabular}

Berdasarkan hasil pengujian hipotesis diketahui bahwa : 1) Psychological empowerment memiliki pengaruh signifikan sebagai variabel mediasi kepemimpian transformasional terhadap perilaku inovatif karena nilai $\mathrm{P}$ values $<0.05 .2)$ Psychological empowerment tidak memiliki pengaruh signifikan sebagai variabel mediasi kepemimpian transaksional terhadap perilaku inovatif karena nilai $P$ values $>0.05$.

Hasil pengujian koefisien determinasi (R Square) ditampilkan dalam tabel dibawah ini:

Tabel 5. $R$ Square Adjusted

\begin{tabular}{lcc}
\hline & R Square & R Square Adjusted \\
\hline Innovative behavior & 0.450 & 0.433 \\
Psychological empowerment & 0.799 & 0.789
\end{tabular}

Berdasarkan table 5, diketahui bahwa nilai Adjusted $\mathrm{R}$ Square variabel Innovative behavior adalah sebesar 0.433 . Hal ini memiliki makna bahwa variabel variabel kepemimpinan transformasional, kepemimpinan transaksional dan psychological empowerment dapat menjelaskan varians dari variabel innovative behavior sebesar 43\%. Nilai Adjusted R Square variabel Psychological empowerment adalah sebesar 0.789. Hal ini memiliki makna bahwa variabel variabel kepemimpinan transformasional dan kepemimpinan transaksional dapat menjelaskan varians dari variabel psychological empowerment sebesar $79 \%$.

\section{Pembahasan}

Berdasarkan hasil pengujian hipotesis diketahui bahwa kepemimpinan transformasional memiliki pengaruh yang positif" dan signifikan terhadap perilaku inovatif baik secara langsung maupun dimediasi oleh variabel psychological empowerment. Hasil pengujian ini memiliki makna bahwa dengan semakin efektifnya penerapan gaya kepemimpinan transformasional maka akan menstimulasi karyawan untuk berperilaku inovatif.

Temuan penelitian ini sejalan dengan beberapa penelitian terdahulu yang dilakukan oleh (Kresnandito, 2012; Parashakti et al., 2016) yang menunjukan adanya pengaruh langsung yang signifikan antara variabel kepemimpinan transformasional terhadap perilaku inovatif. Pada penelitian para peneliti menguji pada karyawan radio dan juga pada karyawna bank dan hasilnya menjukan bahwa karyawan enjadi lebih inovatif dengan adanya penerapan gaya kepemimpinan transformasional. Hasil temuan ini sedikit berbeda dengan hasil penelitian (Günzel-Jensen, Hansen, Jakobsen, \& Wulff, 2018; Pieterse et al., 2010) yang menunjukan bahwa kepimpinan transformasional tidak memiliki pengaruh signifikan terhadap perilaku inovatif dan baru memiliki pengaruh yang signifikan ketika dimediasi oleh variabel psychological empowerment.

Hasil pengujian hipotesis yang selanjutnya menujukan bahwa variabel kepemimpinan transaksional tidak memiliki pengaruh signifikan terhadap perilaku inovatif. Meskipun ada 
hubungan searah antara kepemimpinan transaksional terhadap perilaku inovatif, akan tetapi pengaruh itu tidak cukup besar untuk menstimulasi peningkatan perilaku inovatif. Hasil penelitian yang menunjukan keterkaitan antara kepemimpinan transaksional terhadap perilaku inovatif masih sangat jarang dilakukan.

Terdapat beberapa penelitian yang pernah melakukan pengujian tersebut salah satunya adalah (Günzel-Jensen et al., 2018) yang melakukan penelitian mennujukan bahwa kepemimpinan transaksional tidak memiliki pengaruh signifikan, bahkan hasil penelitian mendapatkan satu temuan mencengangkan bahwa kepemiminan transaksional berpengaruh negatif terhadap perilaku inovatif, itu artinya gaya kepemimpminan yang bedasarkan reward and punishment akan mengurangi perilaku inovatif karyawan (Pieterse et al., 2010)

Berdasarkan hasil pengujian hipotesis diketahui bahwa variabel kepemimpinan transformasional memiliki pengaruh yang positif dan signifikan terhadap psychological empowerment. Temuan penelitian ini memperkuat hasil penelitian terdahulu yang dilakukan oleh Attari, (2013) yang merekomendasikan bahwa administrator rumah sakit perlu mengembangkan keterampilan kepemimpinan transformasional dengan mendapatkan pelatihan yang relevan dan mempromosikan keterampilan tersebut pada supervisor menengah, terutama perawat kepala, untuk secara psikologis memberdayakan staf perawat, sehingga mencapai kepuasan pasien dan kinerja rumah sakit yang lebih tinggi. Begitu juga dengan hasil penelitian yang dilakukan oleh Pradhan, Panda, \& Jena, (2017) dimana hasil penelitiannya menunjukan bahwa kepemimpinan transformasional menjadi faktor yang berpengaruh signifikan terhadap psychological empowermen pada industri ritel yang ada di India.

Berdasarkan hasil penelitian diketahui bahwa kepemimpinan transaksional tidak memiliki pengaruh signifikan terhadap. Variabel kepemimpinan transaksional meskipun arah pengaruhnya positif atau searah tetapi pengaruhnya tidak signifikan terhadap psychological empowerment. Hasil penelitian ini sejalan dengan hasil penelitian (Pieterse et al., 2010) dimana dalam hasil penelitian menujukkan bahwa kepemimpinan transaksional tidak berdampak pada pemberdayaaan psikologis karyawan. hasil penelitian mengenai pengaruh kepemimpinan transaksional terhadap psychological empowerment masih belum banyak dilakukan.

Hasil pengujian hipotesis mengenai pengaruh psychological empowerment terhadap innovative behavior menunjukkan bahwa psychological empowerment memiliki pengaruh yang signifikan terhadap perilaku inovatif. Hasil ini ini sejalan dengan temuan penelitian terdahulu yang dilakukan oleh Singh \& Sarkar, (2012) dimana hasil penelitian menunjukkan bahwa psychological empowerment berpengaruh signifikan terhadap perilaku inovatif.

\section{SIMPULAN}

Berdasarkan hasil penelitian disimpulkan bahwa kepemimpinan transformasional berdampak signifikan pada perilaku inovatif karyawan baik itu secara langsung maupun dimediasi oleh variabel psychological empowerent. Kepemimpinan transaksional tidak berdampak signifikan pada perilaku inovatif karyawan, baik itu secara lansgung maupun dimediasi oleh varibel psychological empowerment. Psychological empowerment dapat meningkatkan perilaku inovatif karyawan. Implikasi manajerial berdasarkan temuan penelitian ini yaitu bahwa pentingnya pimpinan untuk menerapkan gaya kepemimpinan transformatif yang tercermin dari adanya kharisma, mampu memotivasi, menstimulasi kemampuan intelektual serta memahamai personal karyawan dalam membentuk atau menstimulasi perilaku inovatif karyawan. penerapan gaya kepemimpinan transaksional tidak memiliki pengaruh signifikan terhadap perilaku inovatif bahkan pada penelitian (Pieterse et al., 2010) ditemui hasil korelasi negatif antara kepemimpinan transaksional terhadap perilaku inovatif. Hasil penelitian ini belum bisa membuktikan adanya pengaruh signifikan antara kepemimpinan transaksional terhadap perilaku inovatif maupun psychological empowerment. Diperlukan penelitian lebih lanjut untuk 
menguji kembali gaya kepemimpinan transasksional terhadap perilaku inovatif maupun psychological empowerment. Selanjutnya penelitian lebih lanjut perlu untuk mengukur dampak dari perilaku inovatif karyawan terhadap kinerja inovasi serta daya saing organisasi.

\section{REFERENCE}

Aryee, S., Walumbwa, F. O., Zhou, Q., \& Chad, A. (2012). Transformational Leadership , Innovative Behavior, and Task Performance : Test of Mediation and Moderation Processes. Human Performance, 25, 1-25. https://doi.org/10.1080/08959285.2011.631648

Attari, M. (2013). The impact of transformational leadership on nurse psychological empowerment. International Journal of Hospital Research, 2(2), 71-76.

Avolio, B. J., \& Bass, B. M. (1995). Individual consideration viewed at multiple levels of analysis: A multi-level framework for examining the diffusion of transformational leadership. The Leadership Quarterly, 6(2), 199-218. https://doi.org/https://doi.org/10.1016/1048-9843(95)90035-7

Bass, B. M., \& Riggio, R. E. (2006). Transformational Leadership Second Edition. London: Lawrence Erlbaum Associates, Publishers.

Dyer, J., Gregersen, H., \& Christensen, C. M. (2011). The innovator's DNA: Mastering the five skills of disruptive innovators. Harvard Business Press.

Günzel-Jensen, F., Hansen, J. R., Jakobsen, M. L. F., \& Wulff, J. (2018). A two-pronged approach? Combined leadership styles and innovative behavior. International Journal of Public Administration, 41(12), 957-970. https://doi.org/10.1080/01900692.2017.1303711

Jong, J. de, \& Hartog, deanne den. (2007). How leaders influence employees ' innovative behaviour. European Journal of Innovation Management, 10(1), 41-64. https://doi.org/10.1108/14601060710720546

Kleysen, R. F., \& Street, C. T. (2011). Toward a multi-dimensional measure of individual innovative behavior. Journal of Intellectual Capital, 2(3), 284-296. https://doi.org/https://doi.org/10.1108/EUM0000000005660

Kresnandito, A. P. (2012). Pengaruh Persepsi Kepemimpinan Transformasional terhadap Perilaku Inovatif Penyiar Radio. Jurnal Psikologi Industri Dan Organisasi, 1(02), 96-103.

Lako, A. (2004). Kepemimpinan dan Kineja Organisasi. Yogyakarta: Amara Books.

Parashakti, R. D., Rizki, M., \& Saragih, L. (2016). Pengaruh Kepemimpinan Transformasional Dan Budaya Organisasi Terhadap Perilaku Inovatif Karyawan (Studi Kasus Di Pt. Bank Danamon Indonesia). Jurnal Manajemen Teori Dan Terapan, 9(2), 81-96.

Pieterse, A. N., Knippenberg, D. V. A. N., Schippers, M., \& Stam, D. (2010). Transformational and transactional leadership and innovative behavior: The moderating role of psychological empowerment. Journal of Organizational Behavior, 31(4), 609-623. https://doi.org/10.1002/job

Pradhan, R. K., Panda, M., \& Jena, L. K. (2017). Transformational leadership and psychological empowerment. Journal of Enterprise Information Management. Journal of Enterprise Information Management, 30(1), 82-95. https://doi.org/10.1108/JEIM-01-2016-0026

Robbins, S. P., \& Judge, T. A. (2018). Perilaku Organisasi. Jakarta: Salemba Empat.

Singh, M., \& Sarkar, A. (2012). The Relationship Between Psychological Empowerment and Innovative Behavior A Dimensional Analysis With Job Involvement as Mediator. Journal of Personnel Psychology, 11(3), 127-137. https://doi.org/10.1027/1866-5888/a000065

Spreitzer, G. M. (1995). Psychological Empowerment In The Workplace: Dimensions, Measurement, And Validation. Academy of Management Journal, 38(5), 1442-1465. 